\title{
Pengembangan bahan ajar berbasis react (relating, experiencing, applying, cooperating, transferring) berbantuan advance organizer pada materi larutan penyangga untuk peserta didik SMA/MA kelas XI
}

\author{
Ilma Ade Restantri, Endang Budiasih*, Dedek Sukarianingsih \\ Universitas Negeri Malang, Jl. Semarang No. 5 Malang, Jawa Timur, Indonesia \\ *Penulis korespondensi, Surel: endang.budiasih.fmipa@um.ac.id
}

Paper received: 01-06-2021; revised: 15-06-2021; accepted: 30-06-2021

\begin{abstract}
Abstrak
Pemahaman konsep peserta didik terhadap materi larutan penyangga cukup rendah dan banyak kesulitan yang dialami oleh peserta didik terhadap beberapa konsep. Hal ini disebabkan karena penggunaan bahan ajar yang bersifat deskriptif. Bahan ajar kimia masih berupa buku teks yang menuntut peserta didik untuk menghafal bukan memperoleh pengetahuannya sendiri, sehingga berakibat pada hasil belajar peserta didik. Salah satu solusi untuk mengatasi permasalahan ini adalah mengembangkan bahan ajar dengan model pembelajaran berbasis kontekstual yaitu REACT karena sesuai dengan karakteristik materi larutan penyangga dengan melibatkan peserta didik dalam proses pembelajaran yang nyata. Adanya advance organizer dalam bahan ajar digunakan sebagai penguat struktur kognitif peserta didik yaitu memberikan gambaran mengenai keterkaitan antar konsep pada materi larutan penyangga. Penerapan model REACT berbantuan advance organizer diharapkan dapat membantu peserta didik mempelajari materi secara keseluruhan dan pembelajaran menjadi lebih bermakna. Penelitian dan pengembangan ini menggunakan model pengembangan Four-D oleh Thiagarajan, et all (1974) yang terdiri dari 4 tahapan yaitu define, design, develop, dan disseminate. Penelitian ini hanya sampai pada tahap ketiga yaitu develop. Produk yang dikembangkan berupa bahan ajar yang divalidasi oleh tiga validator yaitu satu orang dosen dan dua orang guru. Data yang dihasilkan berupa data kualitatif dan kuantitatif yang dianalisis dengan teknik analisis persentase dan deskripsi kualitatif. Hasil validasi terhadap buku guru dan buku peserta didik diperoleh rata-rata persentase kelayakan isi sebesar 85,60 persen, kelayakan penyajian dan bahasa sebesar 89,20 persen, serta kelayakan perangkat pembelajaran sebesar 86,70 persen. Hasil uji keterbacaan diperoleh rata-rata persentase aspek tampilan sebesar 92 persen, aspek penyajian materi sebesar 85,60 persen, dan aspek manfaat sebesar 94,80 persen. Berdasarkan kriteria kelayakan bahan ajar menurut Riduwan (2013), bahan ajar yang dikembangkan sangat layak digunakan sebagai sumber belajar.
\end{abstract}

Kata kunci: bahan ajar; REACt, advance organizer; larutan penyangga

\section{Pendahuluan}

Menurut Chang (2005) ilmu kimia adalah ilmu dasar yang membahas mengenai suatu materi dan perubahan yang menyertainya. Konsep dalam ilmu kimia merupakan konsep yang bertingkat dan berkembang dari konsep sederhana menjadi lebih kompleks (Zidny, dkk., 2013). Konsep kimia bersifat berjenjang yaitu materi sebelumnya menjadi dasar pembahasan untuk materi selanjutnya. Salah satu materi kimia yang memenuhi kriteria tersebut adalah larutan penyangga. Sihaloho (2013) menyatakan bahwa larutan penyangga merupakan materi esensial yang sebagian konsepnya bersifat abstrak. Hasil wawancara dengan beberapa peserta didik di salah satu SMA terhadap materi larutan penyangga menunjukkan bahwa peserta didik mengalami kesulitan dalam memahami beberapa konsep materi. Kesulitan yang dialami peserta didik ini menyebabkan pemahaman konsep menjadi rendah terhadap materi larutan penyangga. Salah satu faktor penyebabnya adalah penggunaan bahan ajar yang digunakan tidak mendukung kemampuan peserta didik untuk berpikir sehingga peserta didik 
cenderung untuk menghafal berbagai informasi yang terdapat dalam bahan ajar (Mentari, dkk., 2014).

Bahan ajar merupakan salah satu komponen yang penting dalam proses pembelajaran. Pembelajaran tidak akan berlangsung secara maksimal, apabila tidak didukung dengan penggunaan bahan ajar yang berkualitas baik (Anwar, dkk., 2017). Bahan ajar yang baik merupakan bahan ajar yang sistematis, runtut, dan tidak terfokus pada materi dan rumus saja, tetapi juga menuntun peserta didik dalam proses pembentukan konsep pada materi yang diajarkan. Sihombing \& Marheni (2012) menyatakan bahwa bahan ajar merupakan sarana penting untuk menyampaikan informasi dan pesan tertulis kepada peserta didik dalam proses pembelajaran. Penggunaan bahan ajar yang sesuai dapat mempermudah guru dalam proses pembelajaran, dan memberikan dampak positif pada proses perkembangan belajar peserta didik.

Ketersediaan bahan ajar di lapangan sangat bervariasi. Penelitian yang dilakukan Gusta (2016) menyatakan bahwa materi dalam buku teks disajikan secara langsung, dan terpaku terhadap rumus-rumus yang digunakan. Penyajian materi larutan penyangga lebih ditekankan pada aspek perhitungan pada proses belajar dibandingkan dengan materi aplikasi (Stephanie, dkk., 2011). Penyajian bahan ajar ini menyebabkan peserta didik tidak dilibatkan secara langsung dalam proses pembelajaran, sehingga ketika mengerjakan soal-soal latihan peserta didik cenderung melihat uraian materi pada bahan ajar.

Berdasarkan hal tersebut dapat disimpulkan bahwa bahan ajar yang beredar saat ini tidak dapat memenuhi kebutuhan peserta didik karena belum memuat kegiatan penemuan konsep sehingga kurang mengoptimalkan keaktifan peserta didik dalam proses pembelajaran, sehingga diperlukan suatu pengembangan bahan ajar yang mengimplementasikan kurikulum 2013 yaitu proses pembentukan kompetensi peserta didik dengan berbasis kontekstual salah satunya menggunakan model pembelajaran REACT. Model REACT menurut Crawford (2001) terdiri dari lima tahap yaitu relating (mengaitkan), experiencing (mengalami), applying (menerapkan), cooperating (bekerja sama), dan transferring (mentransfer). Setiap tahapan memiliki fungsi khusus untuk menyumbangkan proses belajar yang dikaitkan dengan asumsi tentang aktivitas mental dan fisik peserta didik. Pembelajaran kontekstual dipilih karena sesuai dengan karakteristik materi larutan penyangga yaitu bersifat kontekstual atau erat hubungannya dengan kehidupan sehari-hari (Durotulaila, dkk., 2014).

Bahan ajar berbasis REACT merupakan bahan ajar yang membimbing peserta didik untuk membangun pengetahuannya dengan menganalisis dan memecahkan permasalahan atau peristiwa dan fenomena dalam kehidupan sehari-hari sehingga proses pembelajaran menjadi lebih bermakna. Kebermaknaan proses pembelajaran menjadikan struktur kognitif peserta didik menjadi tertata. Pembelajaran bermakna tidak hanya menggambarkan pengalaman peserta didik terhadap lingkungan tetapi juga kemampuan untuk menghubungkan antar satu konsep yang telah dipelajari dengan konsep yang sedang dipelajari. Hal ini mengacu pada karakteristik ilmu kimia yaitu konsepnya bersifat berjenjang. Iskandar (2015) menjelaskan bahwa pembelajaran bermakna terjadi apabila pengetahuan baru terasimilasi pada konsep yang sudah ada sehingga akan tersimpan lama dalam skema atau struktur kognitif peserta didik. 
Penerapan model REACT perlu diintegrasikan dengan dengan suatu alat bantu yaitu advance organizer (Hartiningsih, 2018) yang dapat menghubungkan keterkaitan antar materi larutan penyangga. Advance organizer membimbing peserta didik untuk mengidentifikasi konsep dalam materi serta menghubungkan beberapa konsep tersebut untuk membangun pengetahuan yang lebih rinci. Pembelajaran kimia berbasis REACT berbantuan advance organizer ini belum tersedia bahan ajarnya, sehingga perlu untuk dikembangkan. Bentuk advance organizer dalam penelitian pengembangan ini adalah peta konsep yang diperkuat dengan deskripsi materi prasyarat dari larutan penyangga. Peta konsep yang disajikan oleh guru secara rinci dan runtut akan memberikan hubungan diantara satu konsep dengan konsep lainnya (Korur, et al., 2016). Perpaduan antara REACT dan advance organizer diharapkan peserta didik dapat mengonstruksi pemahaman konsep lebih dalam dan terstruktur.

\section{Metode}

Penelitian dan pengembangan ini menggunakan model Four-D yang dikembangkan oleh Thiagarajan, Semmel, dan Semmel pada tahun 1974. Tahapan dalam pengembangan Four-D meliputi define (pendefinisian), design (perencanaan), develop (pengembangan), dan disseminate (penyebaran). Pengembangan dilakukan sampai tahap ketiga saja, tahapan disseminate tidak dilakukan karena tujuan dari pengembangan hanya terbatas untuk menguji kelayakan produk yang dihasilkan, serta adanya faktor lain yaitu keterbatasan waktu dan biaya.

Hasil akhir dari penelitian ini adalah bahan ajar cetak yang terdiri dari buku peserta didik dan buku guru. Bahan ajar yang dihasilkan divalidasi oleh satu orang dosen kimia dan dua orang guru kimia SMA Negeri 1 Sumberpucung. Uji keterbacaan dilakukan pada sepuluh peserta didik kelas XII SMA Negeri 1 Sumberpucung yang telah memperoleh materi larutan penyangga. Lembar penilaian untuk validasi dan uji keterbacaan menggunakan angket dengan penilaian skala likert lima tingkatan. Hasil validasi diperoleh data kualitatif berupa saran dan komentar dari validator dan subjek uji keterbacaan untuk memperbaiki bahan ajar. Sedangkan data kuantitatif yang diperoleh kemudian dianalisis untuk mengetahui bagaimana tingkat kelayakan dari bahan ajar yang dikembangkan dengan menggunakan teknik perhitungan persentase sebagai berikut.

$$
P=\frac{\sum X}{n} \times 100 \%
$$

Keterangan:

$$
\begin{array}{ll}
\mathrm{P} & : \text { Persentase } \\
\sum \mathrm{X} & \text { : Jumlah nilai } \\
\mathrm{n} & \text { : Jumlah skor maksimal }
\end{array}
$$

Berdasarkan hasil tersebut, dapat diperoleh kesimpulan bahwa bahan ajar yang telah dikembangkan layak atau tidak layak digunakan dalam proses pembelajaran mengacu pada kriteria intrepretasi penilaian bahan ajar menurut Riduwan (2013). Kriteria intrepretasi skor penilaian bahan ajar dapat dilihat pada tabel 1.1. 
Tabel 1.1 Kriteria Interpretasi Skor Penilaian Bahan Ajar

\begin{tabular}{|l|l|l|}
\hline No. & Persentase & Kriteria Kelayakan \\
\hline 1. & $0 \%-20 \%$ & Sangat tidak layak digunakan sebagai bahan ajar \\
\hline 2. & $21 \%-40 \%$ & Kurang layak digunakan sebagai bahan ajar \\
\hline 3. & $41 \%-60 \%$ & Cukup layak digunakan sebagai bahan ajar \\
\hline 4. & $61 \%-80 \%$ & layak digunakan sebagai bahan ajar \\
\hline 5. & $81 \%-100 \%$ & Sangat layak digunakan sebagai bahan ajar \\
\hline
\end{tabular}

(Sumber: Riduwan, 2013:18)

\section{Hasil dan Pembahasan}

\subsection{Hasil}

\subsubsection{Validasi Buku Peserta Didik}

Validasi buku peserta didik meliputi aspek kelayakan isi, kelayakan bahasa, dan kelayakan penyajian yang telah divalidasi oleh tiga orang validator. Rata-rata persentase hasil validasi buku peserta didik tertera pada tabel 1.2 sampai tabel 1.3.

Tabel 1.2 Rata-Rata Persentase Kelayakan Isi Buku Peserta Didik

\begin{tabular}{|c|c|c|c|}
\hline No. & Aspek yang Dinilai & $\begin{array}{l}\text { Rata-Rata } \\
\text { Persentase (\%) }\end{array}$ & Keterangan \\
\hline 1. & $\begin{array}{l}\text { Kesesuaian bahan ajar dengan kompetensi } \\
\text { dasar. }\end{array}$ & 87,7 & $\begin{array}{l}\text { Sangat } \\
\text { Layak }\end{array}$ \\
\hline 2. & $\begin{array}{l}\text { Indikator dirumuskan dengan jelas dan sesuai } \\
\text { dengan kompetensi dasar. }\end{array}$ & 87,7 & $\begin{array}{l}\text { Sangat } \\
\text { Layak }\end{array}$ \\
\hline 3. & $\begin{array}{l}\text { Kedalaman dan keluasan materi sesuai dengan } \\
\text { tujuan pembelajaran. }\end{array}$ & 93,3 & $\begin{array}{l}\text { Sangat } \\
\text { Layak }\end{array}$ \\
\hline 4. & $\begin{array}{l}\text { Materi yang disajikan sesuai dengan } \\
\text { kebenaran keilmuan. }\end{array}$ & 80 & Layak \\
\hline $\begin{array}{l}5 . \\
6 .\end{array}$ & $\begin{array}{l}\text { Kelogisan dan sistematika penyajian. } \\
\text { Penyaiian materi memudahkan peserta didik }\end{array}$ & 80 & Layak \\
\hline & $\begin{array}{l}\text { dalam menganalisis keterkaitan antara fakta } \\
\text { dengan konsep dan antara konsep dengan } \\
\text { konsep. }\end{array}$ & 93,3 & $\begin{array}{l}\text { Sangat } \\
\text { Layak }\end{array}$ \\
\hline 7. & $\begin{array}{l}\text { Kemudahan isi bahan ajar untuk dipahami } \\
\text { peserta didik. }\end{array}$ & 73,3 & Layak \\
\hline 8. & $\begin{array}{l}\text { Langkah-langkah kegiatan belajar } \\
\text { memudahkan peserta didik dalam menemukan } \\
\text { konsep. }\end{array}$ & 86,7 & $\begin{array}{l}\text { Sangat } \\
\text { Layak }\end{array}$ \\
\hline 9. & $\begin{array}{l}\text { Fase advance organizer memudahkan peserta } \\
\text { didik untuk menggali dan memulihkan kembali } \\
\text { ingatan mengenai pengetahuan awal. }\end{array}$ & 86,7 & $\begin{array}{l}\text { Sangat } \\
\text { Layak }\end{array}$ \\
\hline 10. & $\begin{array}{l}\text { Fase relating memudahkan peserta didik untuk } \\
\text { memfokuskan perhatian dan minat terhadap } \\
\text { materi yang dipelajari yang mana dihubungkan } \\
\text { dengan peristiwa dalam kehidupan sehari-hari. }\end{array}$ & 86,7 & $\begin{array}{l}\text { Sangat } \\
\text { Layak }\end{array}$ \\
\hline 11. & $\begin{array}{l}\text { Fase experiencing memudahkan peserta didik } \\
\text { dalam mengeksplorasi materi dan gagasan baru. }\end{array}$ & 86,7 & $\begin{array}{l}\text { Sangat } \\
\text { Layak }\end{array}$ \\
\hline 12. & $\begin{array}{l}\text { Fase applying memudahkan peserta didik untuk } \\
\text { lebih memahami terhadap materi yang dipelajari. }\end{array}$ & 93,3 & $\begin{array}{l}\text { Sangat } \\
\text { Layak }\end{array}$ \\
\hline
\end{tabular}


13. Fase cooperating memberikan kesempatan peserta didik untuk saling berkomunikasi, berdiskusi, dan bekerja sama dengan teman.

93,3

73,3

80

Gambar atau tabel yang disajikan sesuai dengan materi pelajaran yang dibahas.

\begin{tabular}{ccc}
\hline Total Rata-Rata Persentase & 85,6 & $\begin{array}{c}\text { Sangat } \\
\text { Layak }\end{array}$ \\
\hline Tabel 1.3 Rata-Rata Persentase Kelayakan Bahasa dan Penyajian Buku Peserta \\
Didik
\end{tabular}

\begin{tabular}{|c|c|c|c|}
\hline No. & Aspek yang Dinilai & $\begin{array}{l}\text { Rata-Rata } \\
\text { Persentase } \\
(\%) \\
\end{array}$ & Keterangan \\
\hline \multicolumn{4}{|c|}{ Kebahasaan } \\
\hline 1. & Bahasa yang digunakan komunikatif. & 100 & Sangat Layak \\
\hline 2. & Penggunaan istilah dan simbol konsisten. & 80 & Layak \\
\hline 3. & Kemudahan kalimat dipahami oleh pembaca. & 86,7 & Sangat Layak \\
\hline 4. & Kesesuaian dengan kaidah Bahasa Indonesia. & 100 & Sangat Layak \\
\hline \multicolumn{4}{|c|}{ Penyajian } \\
\hline 1. & Keruntutan konsep dalam sajian topik. & 93,3 & Sangat Layak \\
\hline 2. & $\begin{array}{l}\text { Profil bahan ajar dan petunjuk penggunaan } \\
\text { disajikan secara jelas. }\end{array}$ & 86,7 & Sangat Layak \\
\hline 3. & $\begin{array}{l}\text { Isi dan bagian buku dideskripsikan dengan } \\
\text { jelas. }\end{array}$ & 86,7 & Sangat Layak \\
\hline 4. & $\begin{array}{l}\text { Kemampuan sajian topik dalam mendorong } \\
\text { peserta didik untuk mengembangkan } \\
\text { kompetensi berpikir kritis dan pemecahan } \\
\text { masalah. }\end{array}$ & 73,3 & Sangat Layak \\
\hline 5. & $\begin{array}{l}\text { Kemampuan sajian topik dalam memotivasi } \\
\text { peserta didik untuk merespon materi yang } \\
\text { dipelajari. }\end{array}$ & 93,3 & Sangat Layak \\
\hline \multirow{2}{*}{$\begin{array}{l}6 . \\
7 .\end{array}$} & Tampilan bahan ajar menarik. & 93,3 & Sangat Layak \\
\hline & $\begin{array}{l}\text { Jenis dan ukuran huruf memudahkan peserta } \\
\text { didik untuk mempelajari materi atau bahan } \\
\text { yang dikaji. }\end{array}$ & 86,7 & Sangat Layak \\
\hline 8. & $\begin{array}{l}\text { Tabel, gambar, dan skema diletakkan } \\
\text { ditempat yang mudah diamati oleh peserta } \\
\text { didik dengan pemberian jarak spasi yang } \\
\text { sesuai dengan teks. }\end{array}$ & 93,3 & Sangat Layak \\
\hline \multicolumn{2}{|c|}{ Total Rata-Rata Persentase } & 89,2 & Sangat Layak \\
\hline
\end{tabular}

\subsubsection{Validasi Buku Guru}

Validasi buku guru meliputi aspek kelayakan isi, kelayakan bahasa, kelayakan penyajian, dan kelayakan perangkat pembelajaran yang dilakukan oleh tiga validator ahli. Rata-rata persentase hasil validasi buku guru tertera pada tabel 1.4 sampai table 1.6. 
Tabel 1.4 Rata-Rata Persentase Kelayakan Isi Buku Guru

\begin{tabular}{|c|c|c|c|}
\hline No. & Aspek yang Dinilai & $\begin{array}{l}\text { Rata-Rata } \\
\text { Persentase } \\
\text { (\%) }\end{array}$ & Keterangan \\
\hline 1. & $\begin{array}{l}\text { Kesesuaian bahan ajar dengan kompetensi } \\
\text { dasar. }\end{array}$ & 87,7 & Sangat Layak \\
\hline 2. & $\begin{array}{l}\text { Indikator dirumuskan dengan jelas dan } \\
\text { sesuai dengan kompetensi dasar. }\end{array}$ & 87,7 & Sangat Layak \\
\hline 3. & $\begin{array}{l}\text { Kedalaman dan keluasan materi sesuai } \\
\text { dengan tujuan pembelajaran. }\end{array}$ & 93,3 & Sangat Layak \\
\hline 4. & $\begin{array}{l}\text { Materi yang disajikan sesuai dengan } \\
\text { kebenaran keilmuan. }\end{array}$ & 80 & Layak \\
\hline 5. & Kelogisan dan sistematika penyajian. & 80 & Layak \\
\hline 6. & $\begin{array}{l}\text { Penyajian materi memudahkan peserta didik } \\
\text { dalam menganalisis keterkaitan antara fakta } \\
\text { dengan konsep dan antara konsep dengan } \\
\text { konsep. }\end{array}$ & 93,3 & Sangat Layak \\
\hline 7. & Kemudahan isi bahan ajar untuk dipahami. & 73,3 & Layak \\
\hline 8. & $\begin{array}{l}\text { Langkah-langkah kegiatan belajar } \\
\text { memudahkan peserta didik dalam } \\
\text { menemukan konsep. }\end{array}$ & 86,7 & Sangat Layak \\
\hline 9. & $\begin{array}{l}\text { Fase advance organizer memudahkan peserta } \\
\text { didik untuk menggali dan memulihkan } \\
\text { kembali ingatan mengenai pengetahuan awal }\end{array}$ & 86,7 & Sangat Layak \\
\hline 10. & $\begin{array}{l}\text { Fase relating memudahkan peserta didik } \\
\text { untuk memfokuskan perhatian dan minat } \\
\text { terhadap materi yang dipelajari yang mana } \\
\text { dihubungkan dengan peristiwa dalam } \\
\text { kehidupan sehari-hari. }\end{array}$ & 86,7 & Sangat Layak \\
\hline 11. & $\begin{array}{l}\text { Fase experiencing memudahkan peserta didik } \\
\text { dalam mengeksplorasi materi dan gagasan } \\
\text { baru. }\end{array}$ & 86,7 & Sangat Layak \\
\hline 12. & $\begin{array}{l}\text { Fase applying memudahkan peserta didik } \\
\text { untuk lebih memahami terhadap materi yang } \\
\text { dipelajari. }\end{array}$ & 93,3 & Sangat Layak \\
\hline 13. & $\begin{array}{l}\text { Fase cooperating memberikan kesempatan } \\
\text { peserta didik untuk saling berkomunikasi, } \\
\text { berdiskusi, dan bekerja sama dengan teman. }\end{array}$ & 93,3 & Sangat Layak \\
\hline 14. & $\begin{array}{l}\text { Fase transferring memudahkan peserta didik } \\
\text { dalam mengakses hasil belajarnya. }\end{array}$ & 73,3 & Layak \\
\hline 15. & $\begin{array}{l}\text { Gambar atau tabel yang disajikan sesuai } \\
\text { dengan materi pelajaran yang dibahas. }\end{array}$ & 80 & Layak \\
\hline \multicolumn{2}{|c|}{ Total Rata-Rata Persentase } & 85,6 & Sangat Layak \\
\hline
\end{tabular}

Tabel 1.5 Rata-Rata Persentase Kelayakan Bahasa dan Penyajian Buku Guru

\begin{tabular}{llll}
\hline No. $\quad$ Aspek yang Dinilai & $\begin{array}{l}\text { Rata-Rata } \\
\text { Persentase } \\
(\%)\end{array}$ & Keterangan \\
\hline \multicolumn{2}{l}{ Kebahasaan } & & \\
$1 . \quad \begin{array}{l}\text { Bahasa yang digunakan komunikatif dan } \\
\text { mudah dipahami. }\end{array}$ & 100 & Sangat Layak \\
$2 . \quad$ Penggunaan istilah dan simbol konsisten. & 80 & Layak
\end{tabular}




\begin{tabular}{|c|c|c|c|}
\hline 3. & Kemudahan kalimat dipahami oleh pembaca. & 86,7 & Sangat Layak \\
\hline 4. & Kesesuaian dengan kaidah Bahasa Indonesia. & 100 & Sangat Layak \\
\hline 5. & Penggunaan bahasa secara efektif dan efisien. & 86,7 & Sangat Layak \\
\hline \multicolumn{4}{|c|}{ Penyajian } \\
\hline 1. & Keruntutan konsep dalam sajian topik. & 93,3 & Sangat Layak \\
\hline 2. & $\begin{array}{l}\text { Profil bahan ajar dan petunjuk penggunaan } \\
\text { disajikan secara jelas. }\end{array}$ & 86,7 & Sangat Layak \\
\hline 3. & $\begin{array}{l}\text { Isi dan bagian-bagian buku dideskripsikan } \\
\text { dengan jelas. }\end{array}$ & 86,7 & Sangat Layak \\
\hline 4. & $\begin{array}{l}\text { Kemampuan sajian topik dalam mendorong } \\
\text { peserta didik untuk mengembangkan } \\
\text { kompetensi berpikir kritis dan pemecahan } \\
\text { masalah. }\end{array}$ & 73,3 & Sangat Layak \\
\hline 5. & $\begin{array}{l}\text { Kemampuan sajian topik dalam memotivasi } \\
\text { peserta didik untuk merespon materi yang } \\
\text { dipelajari. }\end{array}$ & 93,3 & Sangat Layak \\
\hline \multirow{2}{*}{$\begin{array}{l}6 . \\
7 .\end{array}$} & $\begin{array}{l}\text { Tampilan bahan ajar menarik. } \\
\text { Jenis dan ukuran huruf memudahkan neserta }\end{array}$ & 93,3 & Sangat Layak \\
\hline & $\begin{array}{l}\text { didik untuk mempelajari materi atau bahan } \\
\text { yang dikaji. }\end{array}$ & 86,7 & Sangat Layak \\
\hline 8. & $\begin{array}{l}\text { Tabel, gambar, diletakkan ditempat yang } \\
\text { mudah diamati oleh peserta didik. }\end{array}$ & 93,3 & Sangat Layak \\
\hline \multicolumn{2}{|c|}{ Total Rata-Rata Persentase } & 89,2 & Sangat Layak \\
\hline
\end{tabular}

Tabel 1.6 Rata-Rata Persentase Kelayakan Perangkat Pembelajaran Buku Guru

\begin{tabular}{|c|c|c|c|}
\hline No. & Aspek yang Dinilai & $\begin{array}{l}\text { Rata-Rata } \\
\text { Persentase } \\
\text { (\%) }\end{array}$ & Keterangan \\
\hline 1. & RPP disajikan dengan format yang tepat. & 93,3 & Sangat Layak \\
\hline 2. & $\begin{array}{l}\text { Kompetensi inti dan dasar disajikan dengan } \\
\text { jelas. }\end{array}$ & 100 & Sangat Layak \\
\hline 3. & $\begin{array}{l}\text { Indikator dan tujuan pembelajaran } \\
\text { dirumuskan sesuai kompetensi dasar. }\end{array}$ & 86,7 & Sangat Layak \\
\hline 4. & $\begin{array}{l}\text { Tahapan pembelajaran REACT berbantuan } \\
\text { advance organizer disajikan dengan tepat. }\end{array}$ & 86,7 & Sangat Layak \\
\hline 5. & $\begin{array}{l}\text { Langkah-langkah pembelajaran } \\
\text { dideskripsikan dengan jelas. }\end{array}$ & 86,7 & Sangat Layak \\
\hline 6. & Instrumen penilaian disajikan dengan jelas. & 80 & Layak \\
\hline 7. & Instrumen penilaian sesuai dengan RPP. & 80 & Layak \\
\hline 8. & $\begin{array}{l}\text { Instrumen penilaian mencakup aspek } \\
\text { pengetahuan dan keterampilan peserta didik. }\end{array}$ & 80 & Layak \\
\hline 9. & $\begin{array}{l}\text { Soal evaluasi mengukur hasil belajar peserta } \\
\text { didik. }\end{array}$ & 86,7 & Sangat Layak \\
\hline 10. & $\begin{array}{l}\text { Kunci jawaban disajikan dengan jelas dan } \\
\text { benar. }\end{array}$ & 86,7 & Sangat Layak \\
\hline \multicolumn{2}{|c|}{ Total Rata-Rata Persentase } & 86,7 & Sangat Layak \\
\hline
\end{tabular}

\subsubsection{Data Kualitatif Uji Kelayakan}

Data kualitatif diperoleh dari saran, komentar, dan kritik dari tiga validator ahli. Data kualitatif yang diperoleh ini digunakan sebagai bahan revisi untuk perbaikan bahan ajar yang telah dikembangkan. Hasil komentar dan saran dari validator tertera pada tabel 1.7 sampai tabel 1.8. 
Tabel 1.7 Hasil Komentar dan Saran dari Validator Ahli (Guru Kimia) SMAN 1 Sumberpucung

\begin{tabular}{llll}
\hline No. & $\begin{array}{l}\text { Halaman, paragraf, } \\
\text { baris ke }\end{array}$ & Komentar dan Saran & $\begin{array}{l}\text { Tanggapan } \\
\text { dan Revisi }\end{array}$ \\
\hline 1. & Kegiatan Belajar & $\begin{array}{l}\text { Ditambahkan latihan soal pada } \\
\text { tahap experiencing. }\end{array}$ & Direvisi \\
2. & $\begin{array}{l}\text { Perangkat } \\
\text { Pembelajaran }\end{array}$ & $\begin{array}{l}\text { Pada pedoman penskoran } \\
\text { penilaian laporan praktikum dan } \\
\text { penilaian kisi-kisi soal uji } \\
\text { koman 145 dan 168 }\end{array}$ & Direvisi \\
& & $\begin{array}{l} \\
\text { menghitung skornya. }\end{array}$ & \\
\hline
\end{tabular}

Tabel 1.8 Hasil Komentar dan Saran dari Validator Ahli (Dosen Kimia) Universitas Negeri Malang

\begin{tabular}{|c|c|c|c|}
\hline No. & $\begin{array}{l}\text { Halaman, paragraph, } \\
\text { baris ke }\end{array}$ & Komentar dan Saran & $\begin{array}{l}\text { Tanggapan } \\
\text { dan Revisi }\end{array}$ \\
\hline 1. & $\begin{array}{l}\text { Model pembelajaran } \\
\text { halaman x }\end{array}$ & $\begin{array}{l}\text { Ditambahkan kata REACT pada } \\
\text { judul model pembelajaran } \\
\text { berbantuan advance organizer. }\end{array}$ & Ditambahkan \\
\hline 2. & $\begin{array}{l}\text { Peta Konsep halaman } \\
\text { xxii }\end{array}$ & $\begin{array}{l}\text { Peta konsep diperbaiki lagi } \\
\text { supaya lebih baik. }\end{array}$ & Direvisi \\
\hline 3. & $\begin{array}{l}\text { Kegiatan Belajar } 1 \\
\text { Halaman } 1\end{array}$ & $\begin{array}{l}\text { Penjelasan teori asam-basa } \\
\text { sebelum tahun } 1877 \text {, sebaiknya } \\
\text { dihilangkan. }\end{array}$ & Direvisi \\
\hline 4. & $\begin{array}{l}\text { Kegiatan Belajar } 1 \\
\text { Halaman } 3\end{array}$ & $\begin{array}{l}\text { Gambar molekul proses disosiasi } \\
\mathrm{NaOH} \text { diperbaiki. }\end{array}$ & Direvisi \\
\hline 5. & $\begin{array}{l}\text { Kegiatan Belajar } 1 \\
\text { Halaman } 4\end{array}$ & $\begin{array}{l}\text { Contoh penerapan teori asam- } \\
\text { basa Arrhenius cukup asam } \\
\text { monoprotik. }\end{array}$ & Direvisi \\
\hline 6. & $\begin{array}{l}\text { Kegiatan Belajar } 1 \\
\text { Halaman } 5\end{array}$ & $\begin{array}{l}\text { Arah panah perpindahan elektron } \\
\text { ke atom } \mathrm{H} \text { diperbaiki. }\end{array}$ & Direvisi \\
\hline 7. & $\begin{array}{l}\text { Kegiatan Belajar } 1 \\
\text { Halaman } 6\end{array}$ & $\begin{array}{l}\text { Tanda kesetimbangan pada } \\
\text { proses ionisasi asam dan basa } \\
\text { diperbaiki. }\end{array}$ & Direvisi \\
\hline 8. & $\begin{array}{l}\text { Kegiatan Belajar } 1 \\
\text { Halaman } 7\end{array}$ & $\begin{array}{l}\text { Dicek kembali harga } K_{\mathrm{a}} \text { dari } \mathrm{HSO}_{4}^{-} \text {, } \\
\text { untuk menentukan mana yang } \\
\text { bertindak sebagai asam ketika } \\
\text { bereaksi dengan air }\left(\mathrm{H}_{2} \mathrm{O}\right) \text {. }\end{array}$ & Direvisi \\
\hline 9. & $\begin{array}{l}\text { Kegiatan Belajar } 1 \\
\text { Halaman } 13\end{array}$ & $\begin{array}{l}\text { Kata perut pada penjelasan obat } \\
\text { aspirin diganti dengan dengan } \\
\text { kata lambung. }\end{array}$ & Direvisi \\
\hline 10. & $\begin{array}{l}\text { Perangkat } \\
\text { Pembelajaran } \\
\text { Halaman } 95\end{array}$ & $\begin{array}{l}\text { Dalam penyusunan silabus dan } \\
\text { RPP, komponen advance } \\
\text { organizer dicarikan tempat agar } \\
\text { tidak terkesan terpisah dengan } \\
\text { model pembelajaran REACT. }\end{array}$ & Direvisi \\
\hline
\end{tabular}

\subsubsection{Uji Keterbacaan}

Uji keterbacaan dilakukan pada sepuluh peserta didik Kelas XI SMAN 1 Sumberpucung yang telah menerima materi larutan penyangga. Aspek penilaian pada uji keterbacaan ini meliputi aspek tampilan, aspek penyajian materi, serta aspek 
manfaat. Rata-rata persentase aspek manfaat, penyajian materi, dan tampilan hasil uji keterbacaan tertera pada tabel 1-9 sampai tabel 1.11.

Tabel 1.9 Rata-Rata Persentase Aspek Manfaat Hasil Uji Keterbacaan Peserta Didik

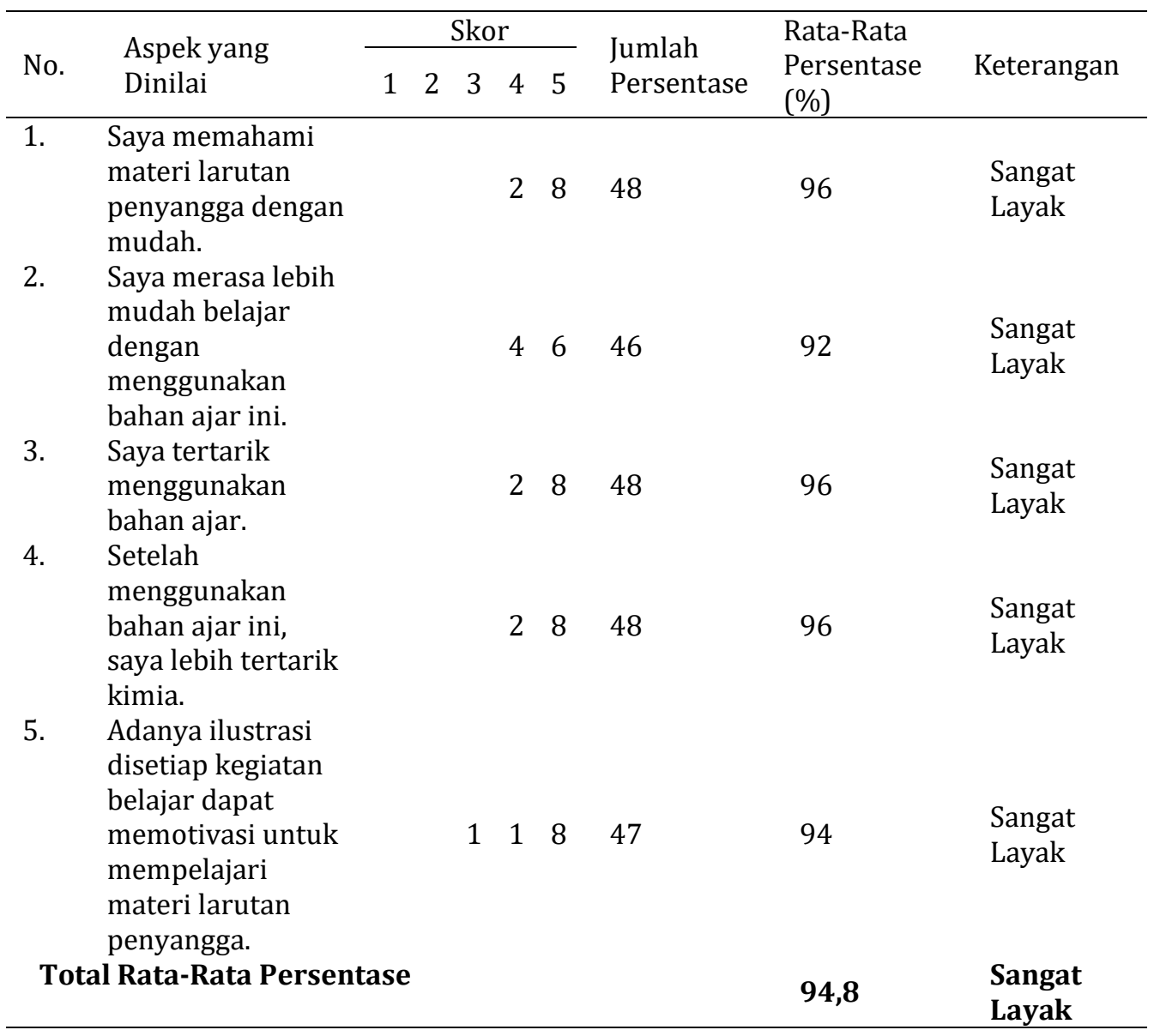

Tabel 1.10 Rata-Rata Persentase Aspek Tampilan Hasil Uji Keterbacaan Peserta Didik

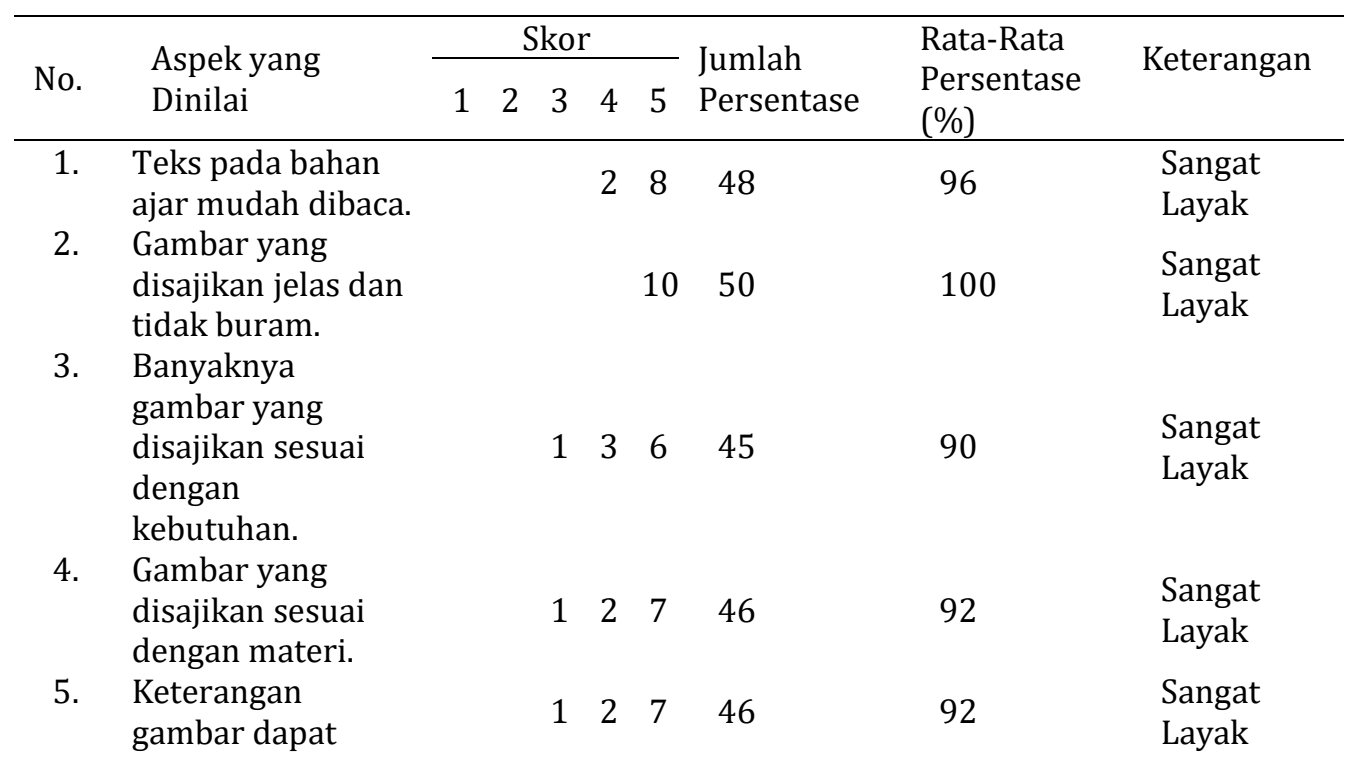


memperjelas

maksud

penyampaian

materi.

6. Gambar disajikan

secara menarik.

$\begin{array}{llll}1 & 7 & 2 & 41\end{array}$

82

Sangat

Total Rata-Rata Persentase

92

Layak

Sangat

Layak

Tabel 1.11 Rata-Rata Persentase Aspek Penyajian Materi Hasil Uji Keterbacaan Peserta Didik

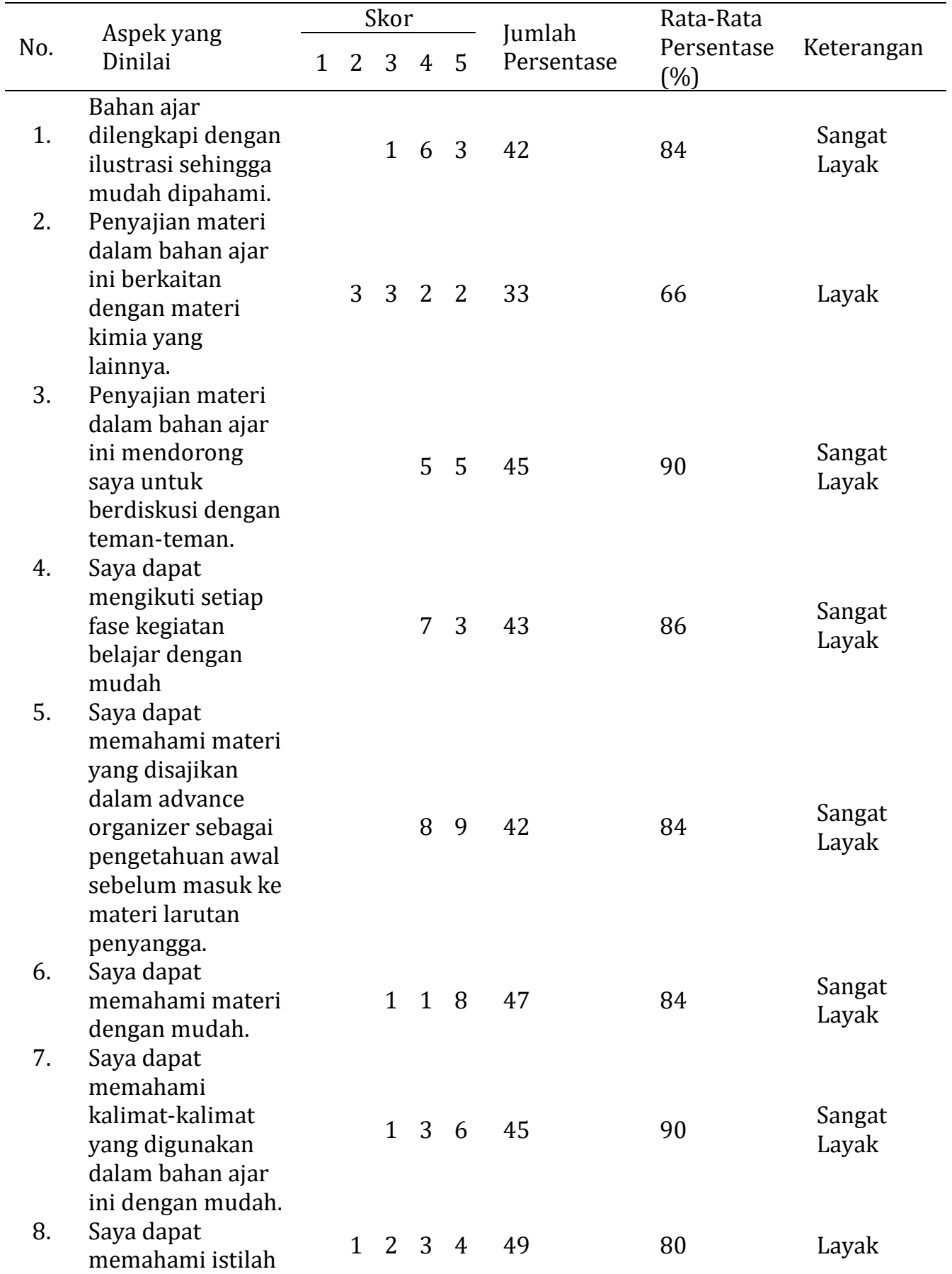


yang digunakan

dalam bahan ajar.

9. Soal-soal yang

digunakan dalam

bahan ajar ini

sudah sesuai

$\begin{array}{lll}2 & 8 & 48\end{array}$

96

Sangat

dengan materi

yang dibahas.

Total Rata-Rata Persentase

$85,6 \quad \begin{array}{ll}\text { Sangat } \\ \text { Layak }\end{array}$

\subsection{Pembahasan}

\subsubsection{Hasil Validasi Buku Peserta Didik}

Tabel 1.2 sampai 1.3 menunjukkan hasil validasi yang dilakukan pada buku peserta didik meliputi aspek kelayakan isi, bahasa dan penyajian. Hasil validasi diperoleh rata-rata persentase dari tiga validator ahli. Rata-rata persentase yang diperoleh dari kelayakan isi sebesar $85,6 \%$, serta kelayakan bahasa dan penyajian sebesar $87,4 \%$. Hasil validasi buku peserta didik dari semua aspek diperoleh rata-rata persentase $\geq 81 \%$. Riduwan (2013:16) menyatakan bahwa bahan ajar dianggap sangat layak bila memenuhi kriteria validitas sebesar $\geq 81 \%$. Berdasarkan pernyataan tersebut, bahan ajar yang dikembangkan sangat layak digunakan dalam pembelajaran materi larutan penyangga untuk peserta didik SMA kelas XI.

\subsubsection{Hasil Validasi Buku Guru}

Berdasarkan Tabel 1.4 sampai 1.6 menunjukkan hasil validasi yang dilakukan pada buku guru meliputi aspek kelayakan isi, bahasa, penyajian serta perangkat pembelajaran. Hasil validasi diperoleh rata-rata persentase dari tiga validator ahli. Rata-rata persentase yang diperoleh dari kelayakan isi sebesar $85,6 \%$, kelayakan bahasa dan penyajian sebesar $89,2 \%$, dan kelayakan perangkat pembelajaran sebesar $86,7 \%$. Hasil validasi buku guru dari semua aspek diperoleh rata-rata skor $\geq 81 \%$. Riduwan (2013:16) menyatakan bahwa bahan ajar dianggap sangat layak layak bila memenuhi kriteria validitas sebesar $\geq 81 \%$. Berdasarkan pernyataan tersebut, bahan ajar yang dikembangkan sangat layak dan dapat digunakan dalam pembela-jaran materi larutan penyangga untuk peserta didik SMA kelas XI.

\subsubsection{Uji Keterbacaan}

Tabel 1.9 sampai 1.11, menunjukkan hasil uji keterbacaan yang dilakukan pada sepuluh peserta didik terhadap bahan ajar yang telah dikembangkan, diperoleh rata-rata persentase dari aspek manfaat sebesar 94,8\%, aspek penyajian materi sebesar $85,6 \%$, serta aspek tampilan sebesar 92\%. Riduwan (2013:18) menyatakan bahwa bahan ajar dianggap sangat layak bila memenuhi kriteria validitas sebesar $\geq 81 \%$. Berdasarkan pernyataan tersebut, bahan ajar yang dikembangkan dapat dikategorikan sangat layak digunakan sebagai sumber belajar materi larutan penyangga untuk peserta didik kelas XI SMA/MA. 


\section{Simpulan}

Kesimpulan yang didapat berdasarkan penelitian dan pengembangan ini adalah (1) dihasilkan bahan ajar materi larutan penyangga penyangga untuk peserta didik SMA/MA kelas XI berbasis REACT berbantaun advance organizer sesuai dengan kompetensi dasar 3.12 dan 4.12 kurikulum 2013 revisi tahun 2017. (2) bahan ajar yang dihasilkan yaitu bahan ajar materi larutan penyangga berbasis REACT berbantuan advance organizer dinyatakan sangat layak digunakan sebagai sumber belajar.

\section{Ucapan Terima Kasih (Opsional)}

Penulis ingin menyampaikan terimakasih kepada: Dr. Hj. Endang Budiasih, M.S. selaku pembimbing I dan Dra. Dedek Sukarianingsih, M.Pd., M.Si selaku pembimbing II yang dengan sabar membimbing dan memberikan saran selama penyusunan skripsi. Terimakasih juga kepada Herunata, S.Pd., M.Pd selaku penguji yang telah membimbing dan memberikan saran serta masukan untuk perbaikan skripsi. Selanjutnya kepada Dr. Sumari, M.Si selaku Ketua Jurusan Kimia dan Dr. Hadi Suwono, M.Si selaku dekan FMIPA Universitas Negeri Malang yang telah memberikan ijin untuk melaksanakan penelitian.

\section{Daftar Rujukan}

Anwar, S., Noviyanti, N., \& Hendrawan, H. (2017). Analisis kelayakan buku teks kimia SMA/MA kelas X materi reaksi redoks berdasarkan kriteria tahap seleksi 4S TMD. Jurnal penelitian pendidikan kimia: kajian hasil penelitian pendidikan kimia, 4(2), 97-104.

Chang, R. (2005). Kimia dasar: konsep-konsep inti. Jakarta: Erlangga.

Crawford, M. L. (2001). Teaching contextually. Research, rationale, and techniques for improving student motivation and achievement in mathematics and science. Texas: Cord.

Durotulaila, A. H. (2014). Pengaruh model pembelajaran react (relating, experiencing, applying, cooperating, transfering) dengan metode eksperimen dan penyelesaian masalah terhadap prestasi belajar ditinjau dari kemampuan analisis siswa (studi pembelajaran larutan penyangga di SMA.

Gusta, S. (2016). Pengembangan bahan ajar materi sifat koligatif larutan dengan model learning cycle 5E untuk siswa kelas XII SMA/MA (Doctoral dissertation, Universitas Negeri Malang).

Hartiningsih, T. (2018). Hasil belajar kognitif dan keterampilan berpikir kritis larutan penyangga sebagai dampak POGIL berbantuan advance organizer di SMA Negeri 1 Papar. Disertasi dan tesis program pascasarjana UM.

Iskandar, S. M. (2015). Pendekatan pembelajaran sains berbasis konstruktivis. Malang: Bayumedia Publishing.

Korur, F., Toker, S., \& Eryllmaz, A. (2016). Effects of the integrated online advance organizer teaching materials on students' science achievement and attitude. Journal of Science Education and Technology, 25(4), 628-640.

Mentari, L., Suardana, I. N., \& Subagia, I. W. (2017). Analisis Miskonsepsi Siswa SMA pada pembelajaran Kimia untuk materi larutan penyangga. Jurnal Pendidikan Kimia Undiksha, 1(1).

Riduwan, M. B. A. (2013). Skala pengukuran variabel-variabel penelitian. Alf. Bandung.

Sihaloho, M. (2013). Analisis kesalahan siswa dalam memahami konsep larutan buffer pada tingkat makroskopis dan mikroskopis. Jurnal Entropi, 8(01).

Sihombing, S. N., \& Marheni, M. (2012). Analisis kebutuhan dalam pembelajaran IPA kimia untuk pengembangan bahan ajar kimia SMP di DKI Jakarta. JRPK: Jurnal Riset Pendidikan Kimia, 2(1), 119126. 
Stephanie, M. M., Slamet, R., \& Purwanto, A. (2011). Pengembangan bahan ajar berbasis kontekstual pada materi larutan penyangga sebagai media pembelajaran SMA IPA kelas XI. JRPK: Jurnal Riset Pendidikan Kimia, 1(1), 1-12.

Zidny, R., Sopandi, W., \& Kusrijadi, A. (2013). Analisis pemahaman konsep siswa SMA kelas X pada materi persamaan kimia dan stoikiometri melalui penggunaan diagram submikroskopik serta hubungannya dengan kemampuan pemecahan masalah. Jurnal Riset dan Praktik Pendidikan Kimia, 1(1), 27-36. 